Research Report

514

\title{
LOW-VOID CONCRETE MIXTURES
}

by

Assaf S. Rahal

Research Engineer Chief

and

James H. Havens

Director

Division of Research

Bureau of Highways

DEPARTMENT OF TRANSPORTATION

Commonwealth of Kentucky

accepted for publication by the

Amerlcan society for Testing and Materlats

December 1978 


\title{
LOW-VOID CONCRETE MIXTURES
}

\author{
by
}

A. S. Ranal and James H. Havens

\begin{abstract}
The purpose of this study was to modify concrete mix-design formulas to supplant all water over and above that needed for hydration with a non-evaporable liquid material and(or) a super-water-reducer or plasticizer -- thus producing a low-void concrete. A water-cement ratio of $0.244-0.30$ was presumed minimal for hydration of the cement. Several polymeric materials, asphalts, oils, and superplasticizers were used, Success was achieved with two latexes, one epoxy, and several superplasticizers. The use of these materials in concrete resulted in improved strength, reduction of air voids and permeability, and enhancement of resistance to corrosive chloride salts.

Keywords: Concrete, Bridge deck, Voids, Durability, Non-evaporable liquids, Latex, Superplasticizers, Epoxy, Corrosion resistance, Permeability.
\end{abstract}




\section{INTRODUCTION}

Extensive research in Kentucky (1, 2, 3) and other states have identified and explained the mechanisms causing premature deterioration of concrete bridge decks. Some suggest that the causal factors have been compounded by the increasingly heavy traffic and widespread use of deicing agents. It is widely recognized that the most destructive forces arise from the absorption and freezing of water within the pores of the mortar and aggregates and corrosion of the embedded steel. These factors lead to scaling, spalling, and structural breakups. Tests have shown repeatedly that damage by freezing and thawing is related directly to rate of water absorption, degree of saturation, and total water content. Corrosion of the steel is also related to the soundness of concrete. Water carrying chloride salts absorbed by the concrete and contacting the steel initiates corrosion which consequently leads to spalling.

If one accepts the hypothesis or premise that the quality of portland cement concrete may yet be improved to provide adequate durability and resistance and to, thereby, assure long-time, maintenance-free service in bridge decks, several improvements are needed. Two basic needs would be (1) the elimination of porous, highly absorptive, reactive, or expansive aggregates and (2) the improvement of the shape or workability features of aggregates to obtain significant reduction in mixing-water in making the concrete. Ideally, protection and assurances against premature deterioration should be a prerequisite consideration in the design of the structure. From the engineer's point of view, this becomes a process of purification and implementations in stages until history provides the necessary proofs and balances. Emerging alternatives have included protective coatings and overlays on normal-quality concrete, use of epoxy-coated reinforcement, injections of polymers into hardened concrete, and cathodic protection.

The intent of this study is to demonstrate, in yet another way, the immunization of concrete against deterioration. Several concepts are employed. The first involves the use of oils and(or) polymerizable liquids to supplant a due portion of mixing water and to fill unwanted spaces in the concrete. Latex-type modifiers have been used rather extensively in Kentucky for patching and overlaying bridge decks. They have been used in lesser concentrations than are considered to be ideally void-filling; that is, the amount of water used has not been limited to that needed for hydration.

The second concept is the use of superplasticizers or super-water reducers to eliminate large portions of the mixing water intended for workability. The superplasticizing admixture disperses the cement agglomerates in such an efficient way that the concrete remains workable at a water-cement ratio near that needed for hydration of the cement. The resulting properties of the concrete are improved in every aspect and are a consequence of the addition of the superplasticizer. There are many superplasticizers available commercially, all of which could be classified under one of three main groups: sulfonated melamine formaldehyde condensates, sulfonated nepthalene formaldehyde condensates, and modified 
lignosulfonates (4). Figures 1 and 2 illustrate the flowing properties of a cement paste at a water-cement ratio of 0.275 before and after a superplasticizer has been added.

Another method which has been suggested as a protection against chloride-induced corrosion of reinforcing steel is the use of internally sealed concrete. Unlike low-void concrete, internally sealed concrete is based on the premise that significant reduction in the penetration of water and freezing-type damage could be realized by mixing wax particles into the fresh concrete and fusing the additives after the concrete has cured. Wax beads in concrete have been used in decks in some other states and in one full-depth bridge deck in Kentucky (5).

Voids occur in concrete through the entrapment of air, the use of excess mixing water, differences in the specific volumes of reactants and hydration products, leaching of hydration products $(\mathrm{CaO})$, and the use of porous aggregates. Only about one-half of the normal mixing water is needed for hydration of the cement (6); the remainder, or excess, is normally required to fluidize the fresh concrete. If the cured concrete is used in a drying environment, most of the excess water evaporates and leaves voids or spaces. The voids which are easily saturated or resaturated upon rewetting affect the durability unfavorably while those which are less permeable are highly favorable to durability. Water occluded in concrete in the form of excess mixing water and water absorbed in the aggregate remains within the mass unless exposed to severe drying conditions. Concrete which has not been allowed to dry following curing may perform poorly upon freezing and thawing (2). Eliminating the permeable voids from the concrete could alleviate many of the shortcomings leading to early deterioration and poor durability.

The largest percentage of voids in the concrete is attributed to the excess mixing water. Excess mixing water is defined here as any water over and above that needed for hydration of the cement. By eliminating most of the excess water, which is needed for workability, and leaving only the amount of water needed for hydration, a watertight, nearly voidless and impermeable concrete could be attained. The workability of the mixture could be provided by either a non-evaporable liquid replacing the excess mixing water -- such liquid could be of the polymeric, asphaltic, or oil type -- or addition of a superplasticizer.

The two critical questions which have to be resolved in order to make the idea of a low-void concrete possible are:

1. What type of material could successfully replace the excess mixing water without adversely affecting the concrete?

2. How much water is needed for hydration of the cement (Type I cement)?

The fluid material to replace the excess mixing water should have the following characteristics:

1. Be a liquid soluble in or emulsifiable with water and have a consistency of water or light 
oil; water should be the continuous phase; may be an inert oil or polymeric compound. Ideally, the disperse phase should remain dispersed thorughout the concrete-mixing process.

2. Be a liquid which would eventually solidify: a latex, epoxy, etc.

3. If solidification is sought, which should take place within a a reasonable time after mixing, the material should exhibit sufficient strength and not contribute to weakening of the hardened concrete.

The super-water-reducing admixture should have the following properties:

1. Be soluble or emulsifiable with water.

2. Not have any adverse affect on the strength or durability of the concrete.

3. Not induce segregation or excessive air entrainment or bleeding.

4. If acceleration or retardation of set is a consequence of the admixture, it should be within acceptable tolerances.

There are different opinions about the amount of water needed for hydration of the cement. The specificity of the amount varies with the type of cement and method of analysis. The extent of hydration appears to be dependent on the amount of water available, time, and compactness of the cement particles. Dense hydration shells or matrices of hydration products slow and perhaps arrest the hydration process. According to Powers (7), portland cement when completely hydrated binds about 0.23 gram of water per gram of cement. This amounts to about $2.6 \mathrm{gal} / \mathrm{bag}\left(2.3 \times 10^{-4} \mathrm{~m}^{3} / \mathrm{kg}\right)$ of cement. It has also been reported (6) that, if only the minimum water needed for hydration is added to the cement, the possibility of near complete hydration is very remote. For this reason, $0.244 \cdot 0.3$ gram of water per gram of cement $(2.75-3.38 \mathrm{gal} / \mathrm{bag}$ of cement, $\mathrm{w} / \mathrm{c}=0.244-0.30)$ was adjudged to be a more practical amount of essential water for the pruposes of this study. Others $(8)$ have indicated a minimum $\mathrm{w} / \mathrm{c}$ of 0.24 .

\section{MATERIALS}

As mentioned previously, the material replacing the mixing water could be either of the polymeric, asphaltic, or oil type or a superplasticizing admixture. Several latex polymers were used; but only two, Dow Latex Modifiers A and B, were considered successful; and one, DuPont chloroprene latex, was unsuccessful. The DuPont latex hardened very fast and made placing the concrete very difficult; the hardened concrete exhibited low strength. One epoxy-type polymer was successfully used. Many other emulsified asphalts and oils were tried but could not be successfully blended into the concrete. Some were abandoned at the mixing stage because the dispersion "broke" before mixing was completed. Three superplasticizers were used successfully: Melment L-10, Mighty 150, and PVP. 


\section{Latexes}

A latex is a water suspension of a polymeric material of either natural or synthetic origin. The latexes used in this study were the following:

A. Dow Latex Modifier A

Polymer Type

Styrene-Butadiene

Stabilizers

(a) Latex

Non-ionic Surfactant

(b) Portland Cement

Composition

Polydimethyl Siloxane

Percent Solids

$46 \cdot 49$

Weight at $25 \mathrm{C}$

$8.4 \mathrm{lb} / \mathrm{gal}\left(100 \mathrm{~kg} / \mathrm{m}^{3}\right)$

Color

White

B. Dow Latex Modifier B

Polymer Type

$75 \%$ Saran

$25 \%$ Styrene-Butadiene

Stabilizers

(a) Latex

Non-ionic Surfactant

(b) Portland Cement

$$
\text { Composition }
$$

Polydimethyl Siloxane

Percent Solids

$47-49$

Weight at $25 \mathrm{C}$

$9.7 \mathrm{lb} / \mathrm{gals}\left(1162 \mathrm{~kg} / \mathrm{m}^{3}\right)$

Color

White

C. Dupont Latex

Polymer Type

Neoprene (Polychloroprene)

Stabilizers

(a) Latex

Non-ionic Surfactant

(b) Portland Cement

2 parts anti-oxidant $/ 100 \mathrm{~g}$ solids

Composition

Percent Solids

48

Weight at $25 \mathrm{C}$

$9.35 \mathrm{lb} / \mathrm{gal}\left(1119 \mathrm{~kg} / \mathrm{m}^{3}\right)$

Color

White

Several other latex systems were tried but could not be successfully mixed into the concrete. The main factors leading to the choice of such systems were their emulsifying and curing properties. All 
three latexes were emulsifiable with water and cured at ambient temperatures within a desirable time.

\section{Emulsified Epoxy Resins}

Epoxy resins are polymers which are mixed with another ingredient to form combinations referred to as formulations. The formulation used in this study consisted of an epoxy resin and a hardener. The hardener reacts with the resin and becomes an integral part of the final plastic material (9).

For the purpose of this study, a formulation had to be emulsifiable with water. Emulsifiable epoxies are not readily available, and a special formulation was developed by Celanese Coatings Company of Louisville, Kentucky. Following are the properties of that EPI-TOP, PC-10 Epoxy:

$\begin{array}{ll}\text { Polymer Type } & \text { Liquid, Bisphenol A, Epoxy Resin } \\ \text { Stabilizers } & \text { Surfactants (water-dispersible) } \\ \text { Percent Solids } & 100 \\ \text { Weight at } 25 \mathrm{C} & 9.6 \mathrm{~b} / \mathrm{gal}\left(1145 \mathrm{~kg} / \mathrm{m}^{3}\right)\end{array}$

\section{Emulsified Asphalts and Oils}

The emulsified asphalts utilized in this study were predominantly of the slow-setting type. Some of the asphalts were paving grade and the others were experimental. The paving grade asphalts included SS-1 and SS-1H (ASTM D-977). The experimental asphalt was a specially formulated emulsion made by the Ashland Oil Company. Emulsified linseed oil was used unsuccessfully.

\section{Superplasticizers (super-water-reducers)}

There are several superplasticizers available commerically. Only three were tested and are reported in this study. A description of each follows:

\section{A. Melment $\mathrm{L}-10$}

Melment L 10 is a 20-percent aqueous solution and, as such, is miscible with water in all proportions. It does not reduce the surface tension of water but acts as a dispersing agent which is absorbed on the surface of the cement particles and the cement is consequently more thoroughly saturated. It is transparent to slightly milky in color and has a slight secondary effect as a hardening accelerator. Melment $\mathrm{L} 10$ has a chloride content of 0.005 percent and weighs $9.18 \mathrm{lb} / \mathrm{gal}\left(1,100 \mathrm{~kg} / \mathrm{m}^{3}\right)$; it is a modified poly-condensation product of melamine and formaldehyde.

\section{B. Mighty 150}

Mighty 150 is a 42-percent aqueous solution and is miscible with water in all proportions. Mighty does not reduce surface tension of its aqueous solution, and the foaming tendency is kept very low, meaning that it does not entrain unwanted air. It has negligilbe effect on the normal hardening of the concrete. It is dark brown in color, has negligible chloride content, and weighs $10.0 \mathrm{lb} / \mathrm{gal}\left(1,200 \mathrm{~kg} / \mathrm{m}^{3}\right)$.

\section{PVP}


PVP is a napthalene sulfonate which is miscible with water in all proportions. It was used as a 40-percent aqueous solution. The solution is dark brown in color and has characteristics very similar to Mighty 150 . The 40 -percent aqueous solution weighs $10 \mathrm{lb} / \mathrm{gal}\left(1,200 \mathrm{~kg} / \mathrm{m}^{3}\right)$.

\section{DESIGN OF MIXTURES}

The mix designs were based on a typical concrete used by the Kentucky Bureau of Highways, Department of Transportation, for bridge decks, namely Class AA concrete, Special Provision No. 35-B. Class AA concrete (Table 1) was used unchanged for the control mixtures designated " $\mathrm{C}$ ". All other mixtures incorporated in them basically the same materials with the following experimental modifications:

1. The water requirement was reduced approximately to that estimated for hydration of the cement.

2. Water needed for workability was compensated for by addition of one of the following:

a. a non-evaporable liquid, added with the water or

b. a superplasticizer, added after all ingredients were thouroughly mixed.

Modified or experimental mixture designs are shown in Table 1.

\section{TEST PROCEDURES}

Latex and emulsified epoxy mixes were extensively tested; all test procedures are described hereafter. As testing of super-water-reducers began, it became apparent that tests for strength, durability, unit weight, and workability were indicative of the integrity of the concrete, due to the inert nature of the super-water-reducers and the resulting densification of the concrete.

\section{Strength}

Unconfined compression tests on all mixtures were made on 6- by 12 -in. (152- by $305-\mathrm{mm}$ ) cylinders in accordance with ASTM C 39. The specimens were molded according to ASTM C 31 in single-use molds conforming to ASTM C 470. All cylinders were covered with wet burlap immediately after molding and were removed from the molds one day later. They were placed in a moisture room and cured until the time of testing. All cylinders were capped and tested in a wet condition.

Flexure tests on all mixtures were run on 3 - by 4 - by 16 -in. (75- by $100-$ by $400-\mathrm{mm}$ ) specimens in accordance with ASTM C 293 (center-point loading). All beams were made according to ASTM C 31 using steel molds. The specimens were removed from the molds one day later and cured in a moisture room until tested. All flexure beams were tested in a wet condition.

Specific Gravity, Absorption, and Voids

Hardened concrete samples of latex and epoxy mixtures were sawed from beams and cylinders and 
tested in accordance with ASTM C 642 for specific gravity, absorption, permeable void volume, and bulk unit weight. The test was modified slightly to insure complete saturation by applying a vacuum to the container while the specimens were immersed in water. Test values listed in Table 2 are average values from three tests.

\section{Air-Void Content}

Air-void content in the hardened latex and epoxy concretes was measured on sawed and polished sections taken from beams and cylinders. The linear traverse method was used in accordance with ASTM C 457. Three samples were tested from each mix. Average results are listed in Table 2.

\section{Freezing and Thawing}

The freezing and thawing tests of all different mixtures was conducted on beams measuring 3 by 4 by $16 \mathrm{in}$. ( 75 by 100 by $400 \mathrm{~mm}$ ). Three beams from each mix were tested in accordance with ASTM C 666. The specimens were cast in steel molds and consolidated by vibration. Finishing was done immediately afterwards; the same procedure was used on each specimen. Wet burlap was placed on the specimens; and, after 24 hours, the specimens were removed and placed in the moisture room where they were cured wet for 13 more days (making a total of 14 days wet cure). The freeze-thaw cycles were started immediately after the curing was discontinued. Prior to placing in the freeze-thaw chamber, the initial, longitudinal, resonant frequency of each beam was measured using a sonometer.

The freezing-and-thawing test ran continuously 7 days a week and continued until each specimen reached 300 cycles of freezing and thawing or until the relative modulus of elasticity diminished to 60 percent of the initial modulus .- whichever occurred first.

\section{Permeability}

A special apparatus was designed and built to measure permeabilities of latex and epoxy concretes. The appartus was similar to that used by Virginia Highway Research Council for permeability studies on aggregates $(10)$. The sample to be tested was cut from a circular cylinder $4 \mathrm{in}$. $(100 \mathrm{~mm})$ in diameter, had parallel ends, and had a thickness of $11 / 8 \mathrm{in.}(29 \mathrm{~mm})$. This sample was mounted in a stainless steel ring, and the margin between the walls of the ring and sample was sealed with epoxy resin to prevent leakage. Care was taken to be sure that the sample was free of cracks and excessively large voids.

The procedure for testing was to vacuum-saturate the sample with distilled water, first allowing enough time for all air to escape. The sample was then surrounded with water on both sides by filling the inlet and outlet sides of the chamber housing it with boiled, distilled water. A capillary tube was connected to the outlet side and filled partially with distilled water. With pressure applied from a nitrogen tank to the inlet side, the flow rate could be measured by monitoring the rise in the capillary tube. 
Measurements were made repeatedly until three, consecutive, consistent readings were obtained. Permeability was calculated for each reading and an average was obtained.

\section{Corrosion Protection}

Two types of laboratory tests were conducted to evaluate the effectiveness of some of the concretes in preventing corrosion. The first test was done on blocks (slabs) and the other on beams. In the first test, the specimens were 14 by 14 by 3.75 in. (356 by 356 by $95 \mathrm{~mm}$ ). In each test block, two No.5 reinforcing bars were centered. One bar was positioned $1 \mathrm{in} .(25 \mathrm{~mm})$ below the surface, the second 2.5 in. $(64 \mathrm{~mm})$ below the surface A copper wire was then soldered to the reinforcing bar nearest the surface and extended through the mold.

Four concretes, Class AA conventional, Latex Modifier A, Latex Modifier B, and PC-10 Epoxy concretes, were used. Three blocks were molded from each mix -- making a total of 12 test specimens.

The concrete was placed in three layers; each layer was mechanically vibrated. After finishing the top surface, the specimens were covered with wet burlap and allowed to cure in their molds for 24 hours. They were then removed and cured in a moist room for the remainder of a 28-day period. A paraffin wall was then constructed around the perimeter of each specimen to provide a pool having a depth of 0.5 in $(12.7 \mathrm{~mm})$ for 3-percent $\mathrm{NaCl}$ solution.

The specimens were placed on a concrete floor in the laboratory and covered with the salt solution; the solution was renewed from time to time. Potential readings of each specimen were made and recorded weekly. The electrical potentials of the reinforcing steel were referenced to a saturated, copper-copper sulfate half-cell. The potential readings were made with a Hewlett Packard, d.c., null voltmeter connected to a half-cell and the steel in the test block. In making readings, the probe was placed on a test block at three locations to determine an average reading.

For the beam test, 12 concrete beams measuring 4.5 by 2.5 by 15 in. (114 by 64 by $380 \mathrm{~mm}$ ) were molded. Three beams were molded from each of the four concretes. A No.-4 reinforcing bar was placed in each test beam so that a minimum of 1 inch $(25 \mathrm{~mm})$ cover was provided. Each reinforcing bar was thoroughly cleaned by sandblasting prior to the molding of the beams. The concrete was placed in three layers and mechanically vibrated. After finishing, the beams were covered with wet burlap and cured 24 hours in their molds. The beams were then immersed in water at a temperature of approximately $73 \mathrm{~F}(23 \mathrm{C})$ for the remainder of the 28-day curing period. After curing, the specimens were transferred to a tank containing a 3-percent solution of sodium chloride. The $\mathrm{NaCl}$ solution was maintained at 3 percent and at a depth of $5 \mathrm{in}$. $(127 \mathrm{~mm})$ throughout the experiment. A plywood cover was placed over the tank to reduce evaporation and aid in the maintenance of the 3-percent $\mathrm{NaCl}$ solution. 
Electrical connections to each rebar was made with spring clips. A set of 12 conductors connected each rebar to a central selector switch. This switch was connected to a Hewlett Packard, d.c., null voltmeter. The switch allowed reading the half-cell potential of the reinforcing bars in all specimens without connecting and disconnecting circuits. The half-cell potentials of the rebars were referenced to a saturated, calomel half-cell. Potential readings were taken several times weekly.

\section{Workability}

Slump tests were conducted on all mixtures immediately after mixing and at 3-minute intervals thereafter.

\section{RESULTS}

\section{Strength}

Results of the compressive and flexure strengths are listed in Table 3. Each value listed represents an average from three specimens.

It is apparent from Figure 3 that all experimental mixtures exhibited higher compressive strengths than the control concrete. Concrete made using super-water-reducers had higher strengths than concrete made with latex and epoxy. Mighty 150 resulted in the highest compressive strength throughout the testing period while Dow Latex Modifier B had the highest strength among the latexes and epoxies.

Whereas latex and epoxy concretes had significantly higher flexural strenghts than the control mix, only Mighty 150 of the superplasticized concretes exceeded the control, and Melment and PVP exhibited lower strengths; this is shown in Figure 4.

The modulus of rupture and compressive strength for the experimental mixtures are related in the same manner as in normal portland cement concrete. This relathionship is shown graphically in Figure $5 \mathrm{a}$ for latex and epoxy mixtures and Figure $5 \mathrm{~b}$ for superplasticized concretes. The relationship for predicting the modulus of rupture from compressive strength is given by

$$
\text { where } \begin{aligned}
\mathrm{f}_{\mathrm{r}}^{\prime} & =\mathrm{K} \sqrt{\mathrm{f}_{\mathrm{c}}} \\
\mathrm{f}_{\mathrm{r}}^{\prime} & =\text { modulus of rupture, } \\
\mathrm{f}_{\mathrm{c}}^{\prime} & =\text { compressive strength, and } \\
\mathrm{K} & =\text { constant. }
\end{aligned}
$$

The value of $\mathrm{K}$ is usually between 8 and 10 . The average value of $\mathrm{K}$ for the Class AA control mixture was 15.5 (15.42 to 15.72); these àverage values were calculated from test data and plotted in Figure 5a. The average values of $\mathrm{K}$ for the other mixtures were:
Dow Latex Modified A
$18.46(17.84$ to 18.78$)$
Dow Latex Modified B
$18.18(17.74$ to 18.78$)$ 


$\begin{array}{ll}\text { PC-10 Epoxy } & 10.96(19.5 \text { to } 20.15) \\ \text { Melment } & 12.4(12.0 \text { to } 12.8) \\ \text { Mighty } 150 & 13.75(12.8 \text { to } 14.7) \\ \text { PVP } & 13.5(12.6 \text { to } 14.4)\end{array}$

\section{Resistance to Rapid Freezing and Thawing}

The test data indicate that latex, epoxy, Melment, and Mighty 150 beams endured the 300 cycles of freezing and thawing specified by ASTM C 666 without failure; PVP beams did not endure to 300 cycles. Further evaluation of the test results follows.

During the progress of the freeze-thaw tests, the specimens were periodically removed and tested for fundamental resonant frequency, from which the relative dynamic modulus was calculated. Figure 6 shows the average, relative, dynamic modulus of elasticity (Table 4) plotted against time expressed as numbers of cycles of freezing and thawing for the various mixtures. It should be noted that a downward trend of the curves indicates deterioration of the specimens. There is a downward inclination in the Dow Latex Modifier, Melment and PVP curves between 160 and 300 cycles. There is no apparent reason for this downward trend (no cracking or scaling). The Mighty and PC 10 Epoxy curves remain constant throughout the 300 cycles.

Since all testing was discontinued after 300 cycles of freezing and thawing, only a limited comparison could be made using the average durability factors. Figure 7 is a bar graph of average durability factors deduced from all specimens in each group.

\section{Permeability}

Table 2 shows the permeabilities for four of the concretes included in this study. The latex mixtures had the lowest permeability (measured zero for all specimens). Also evident is the fact that the control mixture (Class AA concrete) had the highest permeability, more than twice the permeability of PC-10 epoxy concrete.

Table 2 reveals that there is an evident correlation between permeability and absorption on the one hand and permeability and air content on the other. The latex-modified specimens had zero permeability, low absorption, and low air content; the control, Class AA concrete specimens had the highest permeability, absorption, and void content.

\section{Air-Void Content}

This void content does not include capillary passages, voids in the aggregate, or any other submicroscopical openings. The voids are usually larger than $2 \mu \mathrm{m}$ in diameter and are entrapped, entrained, or generated.

In an effort to produce a no-void concrete, no air entrainment was attempted in the experimental 
mixtures. Class AA concrete, which is the control mix, entrained $6 \pm 2$ percent air by volume. The air contents of all fresh concretes were measured shortly after mixing, in accordance with ASTM C 231, and are shown in Table 2.

In freshly mixed concrete, voids could serve two purposes. When distributed uniformly in the form of air bubbles, they tend to fluidize the concrete. The presence of air bubbles could also help reduce the amount of water in the mixture, decrease the water-cement ratio, and enhance strength (2). An excessive percentage of air ( 5 to 8 percent) could, however, be detrimental to strength and durability,

In the hardened concretes, of latex, epoxy, and Class AA, the air content was measured on sawed and polished surfaces using the linear traverse method according to ASTM C 457. By this method, the void and solid volumes are microscopically examined along series of regularly spaced lines, and the percentage of void spaces is determined. The void content for the hardened concrete from each mixture is shown in Table 2. Each value listed is the average void content of three specimens.

It is readily recognizable that all Dow latex and epoxy concretes had lower air-void contents than Class AA concrete. Latex Modifier A concrete exhibited the lowest measured air content (1.92 percent). Class AA concrete exhibited the highest air-void content (3.06 percent). It may be noted that approximately three percent air was lost during the molding of the Class AA concrete.

\section{Corrosion Protection}

The half-cell potential readings of the reinforcing steel on the ponded blocks varied considerably during the 10 months of the corrosion potential test. The reinforcing steel had very high half-cell potentials when referenced to a saturated, copper-copper sulfate electrode. Such unusually high readings would tend to indicate a very active corrosion process occurring on the surface of the reinforcing steel. No cracking or rust stains were observed on the surface of the test blocks, however. At the end of the 10-month period, several of the concrete test blocks were broken in order to inspect the embedded steel. No corrosion was found on any of the reinforcing bars. A plot of potential versus time is shown in Figure 8.

One probable reason for the high potential readings could have been the fact that the reinforcing steel was not sandblasted prior to placement in the concrete. Sandblasting would have removed any oxide film which may have been present on the steel bars. The presence of an oxide film may have caused the readings to appear higher than normal. No other explanation could be found. The test was discontinued and another series of tests on beams were initiated.

Potential readings were made on the beams for a period of 10 months. The results from this test were satisfactory, and a plot of potential versus time is shown in Figure 9. The potential curves for this test (Figure 9) showed a decreasing half-cell potential the first 2 months of the test. Initial, relatively 
high readings were indicative of active corrosion. This was due primarily to corrosion on the exposed portion of the rebar. The corrosion was caused by moisture during the curing process. After several months, the active corrosion of the exposed rebar changed to a passive state and resulted in a passive half-cell potential (lower than $0.27 \mathrm{v}$, referenced to a calomel electrode) (11). During the next 7 to 8 months of the test, the Latex Modifier A, Latex Modifier B, and PC-10 epoxy concrete specimens demonstrated passive and nearly constant half-cell potentials; there was almost no tendency to increase. However, Class AA, conventional concrete specimens showed a small increase in potential during the last 6 months of the test. The increase in potential of Class AA concrete specimens was probably due to the slow penetration of the salt solution to the rebar. Test data after the 10 -month period strongly indicated that the potential in the Class AA specimens was changing to an active state while staying passive in the others. Thus far, corrosion potential measurements are subject to empirical interpretation; the electrochemical basis has not been thoroughly established.

\section{Workability}

There appears to be a slight difference in workability among all the different mixtures having the same slump. Latex, epoxy, and mixtures containing super-water-reducers had a rubbery consistency; more effort was required to work them than Class AA concrete.

Slump-loss test results are shown in Figure 10. All mixtures had an acceptable initial slump of $11 / 2$ to $31 / 2$ in. (38.1 to $88.9 \mathrm{~mm}$ ). Latex Modifier A concrete could be worked up to 30 minutes without revibration and up to 40 minutes upon revibration. Latex Modifier B concrete stiffened more rapidly and reached a slump of 1 in. $(25.4 \mathrm{~mm})$ within 20 minutes. Modifier B concrete responded to revibration after 30 minutes but could not be worked after 40 minutes. The PC-10 epoxy concrete mixture maintained a 2-in. (50.8-mm) slump up to 15 minutes after mixing; between 20 and 30 minutes, the slump diminished rapidly until the mix was unworkable after 30 minutes. Revibration was not very effective in improving the workability of epoxy concretes. More effort was needed to finish epoxy concretes than the latex concretes. Even though the slump-loss test could be interchangeably used to measure both workability and consistency for concretes containing the same materials, it may not be a good indication of workability in the case of latex and epoxy concretes.

The workability of superplasticized concrete is dependent on the amount or dosage of super-water-reducing admixture. All mixtures yielded satisfactory workabilities after the initial addition. (Figure 10). The minimum workability achieved was 47 minutes -- using Mighty 150. Addition of more admixture to the stiffened concrete and revibration revived the workability for approximately 10 additional minutes. 


\section{DISCUSSION AND CONCLUSIONS}

Emphasis in this report, as suggested by the title, has been directed toward reduction of voids in concrete. Figure 11 shows the solids-voids relationships for Class AA concrete and a polymer concrete. It is assumed here that a water-cement ratio of 0.244 is needed for hydration; any water above that amount adds to the void space in the hardened concrete. None of the concretes were entirely voidless, but there was a very significant decrease in void space (actual void space is 1.9 percent for Dow Modifier A compared to 12 percent for Class AA concrete). Other studies (3) on aggregates have shown that a 4-percent absorption, together with near saturation, gives nearly a 100-percent probability of rupture in four cycles of freezing and thawing. The low probability or likelihod of saturation together with a low probability of damage at 1.9-percent porosity (0.8-percent absorption) provide a high degree of assurance against deterioration by freezing and thawing. In the case of Class AA concrete, the probability of deterioration could be high if saturation occurred; there, resistance to freezing and thawing is determined by the improbability of saturation.

The mere number of rapid or slow freezing and thawing cycles which a concrete specimen is able to withstand before saturation becomes critical is probably not as significant as the time-duration of the conditions causing absorption of water and eventual saturation. That is to say, concrete which does not absorb water could withstand any number of cycles of freezing and thawing. So, up to the point of critical saturation, the number of cycles depends upon the freeze-thaw process schedule. This applies to both normal and polymer concretes.

There are other factors which could affect the performance of polymer concretes exposed to heat and freezing and thawing. One which needs to be explored extensively is the thermal expansions and contractions of resins, plastics, and oils in the confined, rigid spaces in the concrete. Plastics, resins, and oils have a higher coefficient of thermal expansion than concrete. This fact could have contributed to the apparent inconsistency in the decrease in dynamic modulus of elasticity of the Dow Modifier mixtures during freezing and thawing。 It would have been very beneficial to this study to have cycled at least a few specimens of the polymer concretes up to temperatures of $150 \mathrm{~F}(66 \mathrm{C})$ or higher. However, this remains an item to be considered in any ensuing researches on concretes of the type demonstrated in this study.

Super-water-reduced, superplasticized concrete resulted in significantly higher strengths than any other concrete mixed previously. Not only did the ultimate strength increase, the early strength increased also, which is advantageous from a construction point of view. This significant leap into low, w/c-ratio concrete and the eagerness for a solution to the bridge deck deterioration problem prompted the recent reconstruction of a US 27 bridge over Silas Creek using Melment L-10 and PVP in two of its four 
spans (5).

Two major problems beset the use of the super-water-reducers on the above-mentioned bridge. The first was the rapid loss of workability。 Laboratory and limited field work with similar mixtures indicated that the concretes would maintain sufficient workability for at least 45 minutes (Figure 10), and that it would be possible to revive the slump by addition of small amounts of the water-reducing admixture. When 8-cubic-yard $\left(6.1-\mathrm{m}^{3}\right)$ batches were attempted under field conditions, the loss of slump and workability was drastic. The initial setting time decreased, and additions of PVP or Melment were only momemtarily effective. The problem was compounded by the method of unloading and placing of the concrete. It took an average of 64 minutes to unload each 8 -cubic-yard $\left(6.1-\mathrm{m}^{3}\right)$ batch of concrete, which made it impossible to maintain workability. The second problem was associated with the finishing equipment. It would have been possible to place and finish the concrete if the finishing machine had been equipped with vibratory, oscillating screeds and a vibrator every 5 feet $(1.52 \mathrm{~m})$ of screed length.

There is reason to believe that an instantaneous type of mixing method which does not require continuous agitation of the ingredients might result in successful concrete mixtures using asphalts and oils and might be very helpful in the production of polymer and superplasticized concretes. The use of retarded admixtures with Melment Mighty 150, and PVP would be a solution. Current work on a retarded version of Mighty 150 has already proven successful.

The use of polymers and super-water-reducers represents a potential contribution towards solving the dilemma of chloride intrusion and deterioration of bridge decks. Further research by this Division on super-water-reducers is underway.

\section{REFERENCES}

1. Havens, J. H.; Thermal Analysis of the Freeze-Thaw Mechanism in Concrete, Bulletin No. 59, Engineering Experiment Station, University of Kentucky, March 1961.

2. Havens, J. H.; Freeze-and-Thaw Penomena in Concretes and Aggregates, Division of Research, Kentucky Department of Highways, March 1970.

3. Havens, J. H.; and Deen, R. C.; A Possible Explanation of Concrete Popouts, presented at the 1977 Annual Meeting of the Transportation Research Board, 1977.

4. Hewlett, Peter; and Rixom, Roger; Superplasticized Concrete, Journal of the American Concrete Institute, May 1977, pp N6-N11.

5. Rahal, A. S.; Voidless and Internally Sealed Concretes, Division of Research, Kentucky Bureau of Highways, February 1977.

6. Troxell, G. E.; Davis, H. E.; and Kelly, J. W.; Composition and Properties of Concrete, Second 
Edition, McGraw-Hill, 1968; p 135.

7. Powers, T. C.; and Brownyard, T. L.; Studies of the Physical Properties of Hardened Portland Cement Paste, Bulletin 22, Portland Cement Association, 1948, pp 972-992.

8. Bogue, R. H.; The Chemistry of Portland Cement, Reinhold, 1955; pp 529 and 671.

9. Winding, C. C.; and Hiatt, G. D.; Polymeric Materials, McGraw-Hill, 1961, pp 262-268.

10. Sherwood, W. C.; Huang, J. H.; Dudash, J. H.; and McGhee, K. H.; Porosity and Permeability Studies of Virginia Aggregates, Virginia Highway Research Council, June 1972.

11. Stratfull, F. F.; Half-Cell Potential and the Corrosion of Steel in Concrete, Materials and Research Department, California Division of Highways, Sacramento, November 1970. 


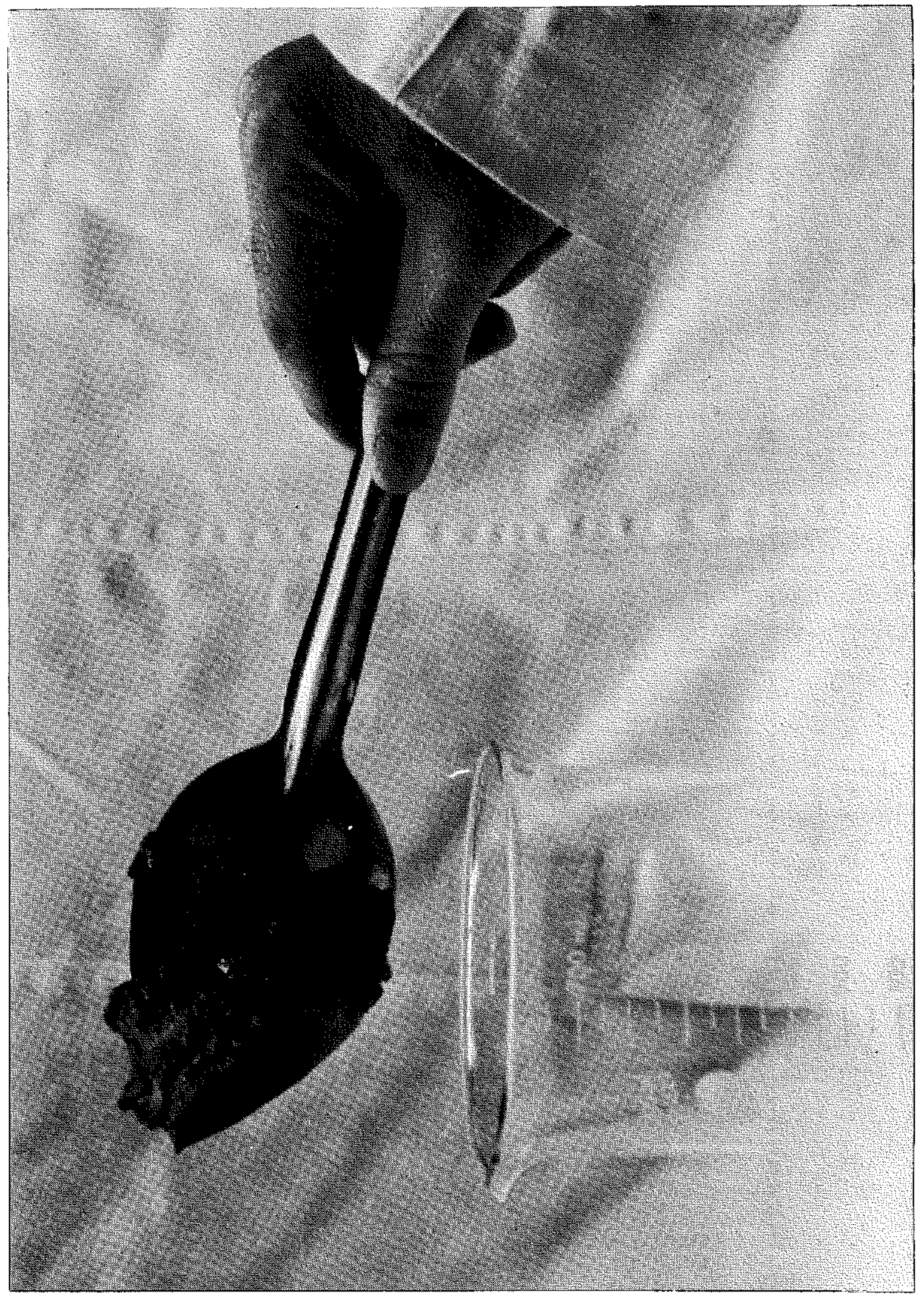

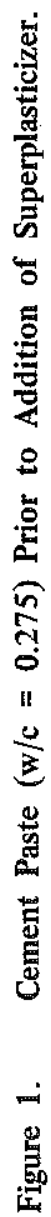




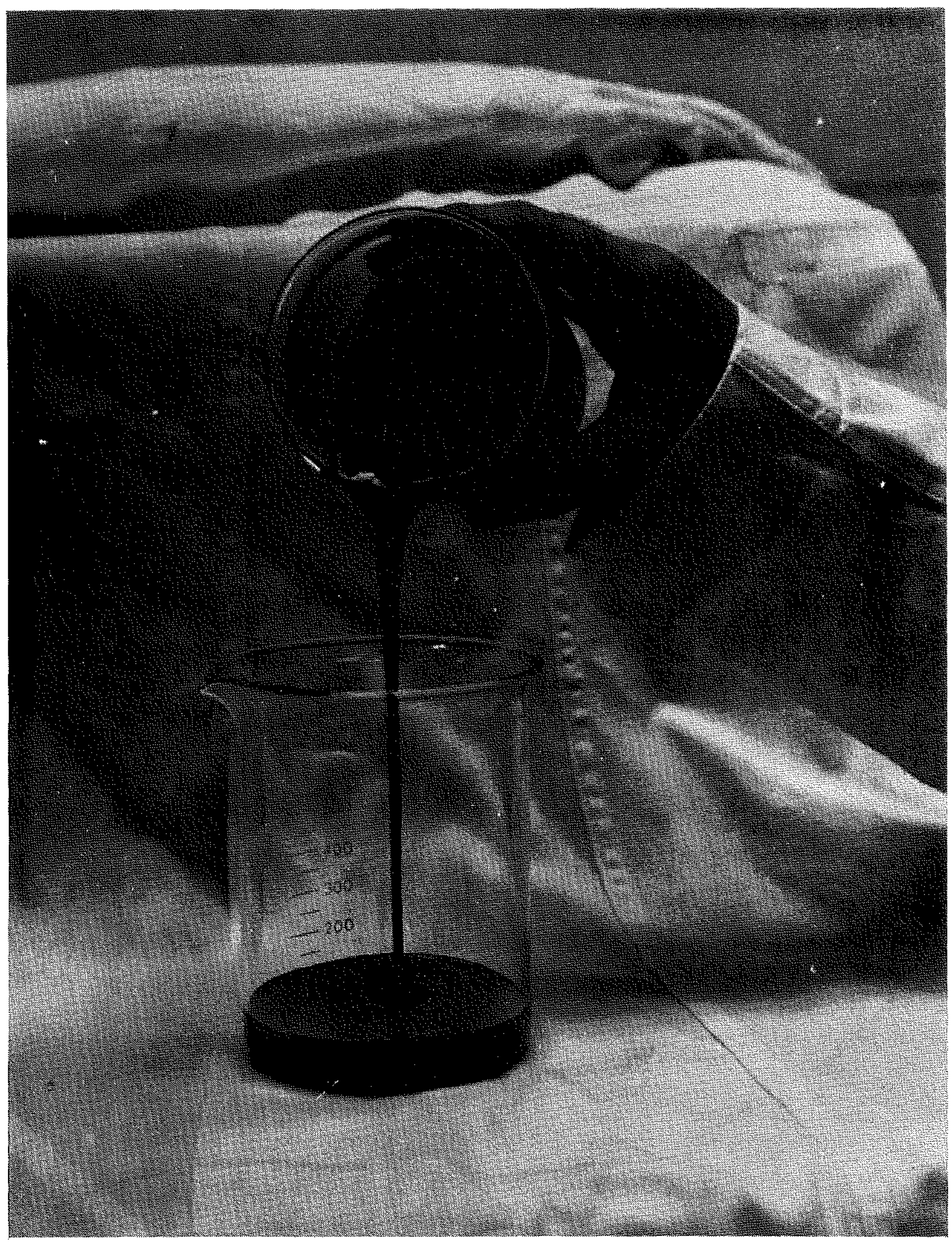

Figure 2. Cement Paste $(w / c=0.275)$ after Addition of Superplasticizer. 


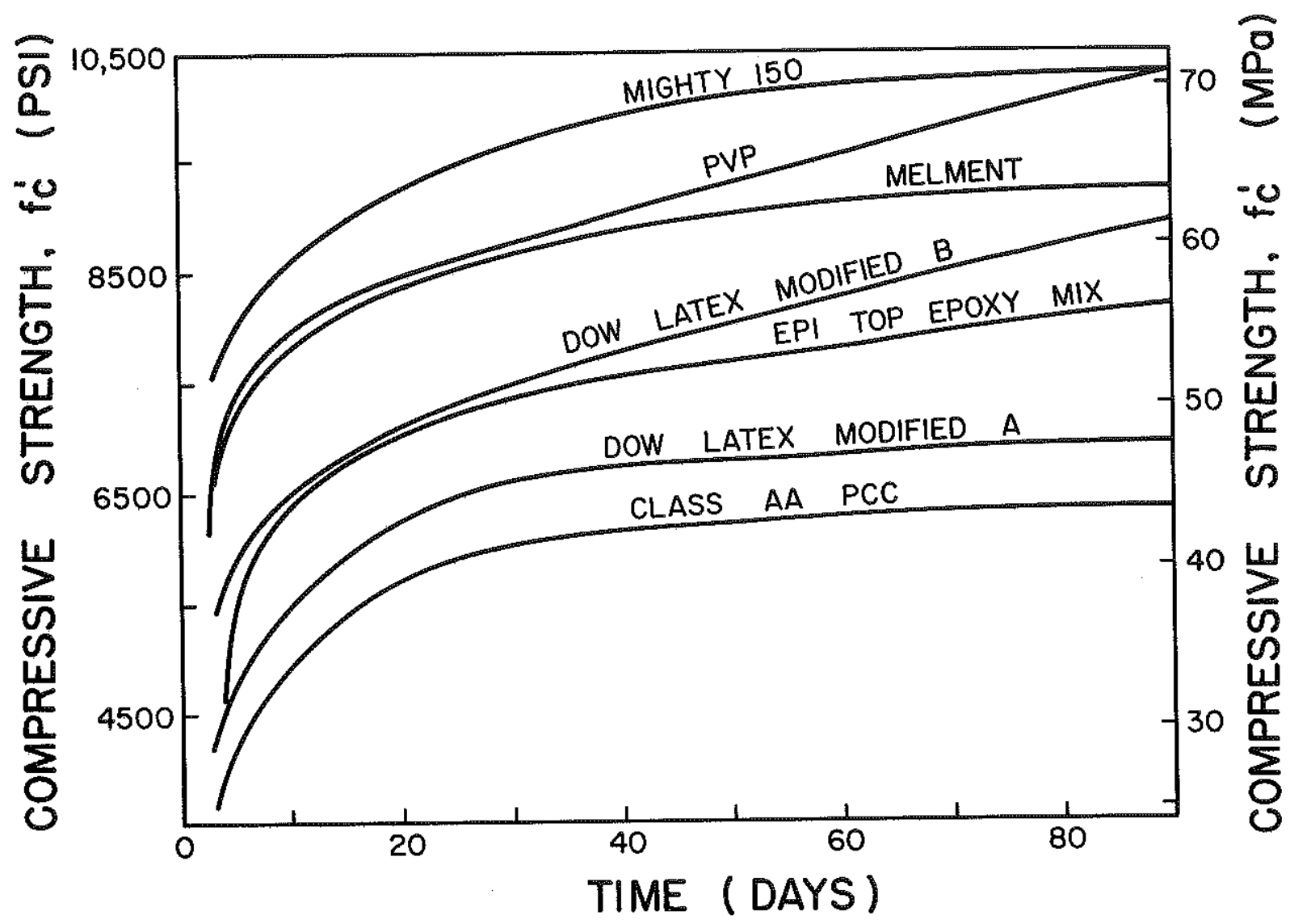

Figure 3. Compressive Strength versus Time; All Mixtures. 

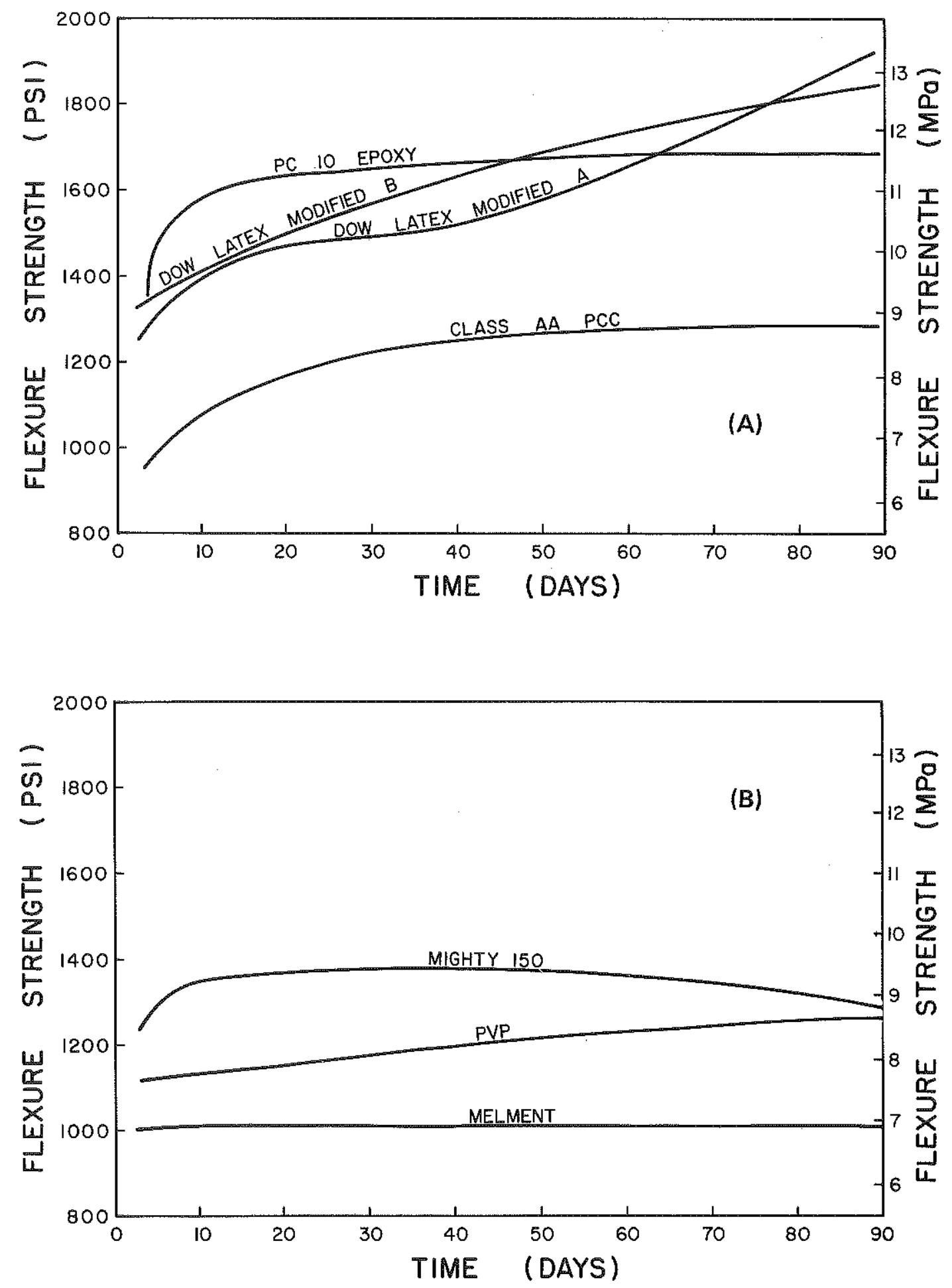

Figure 4. Flexure Strength versus Time; All Mixtures. 


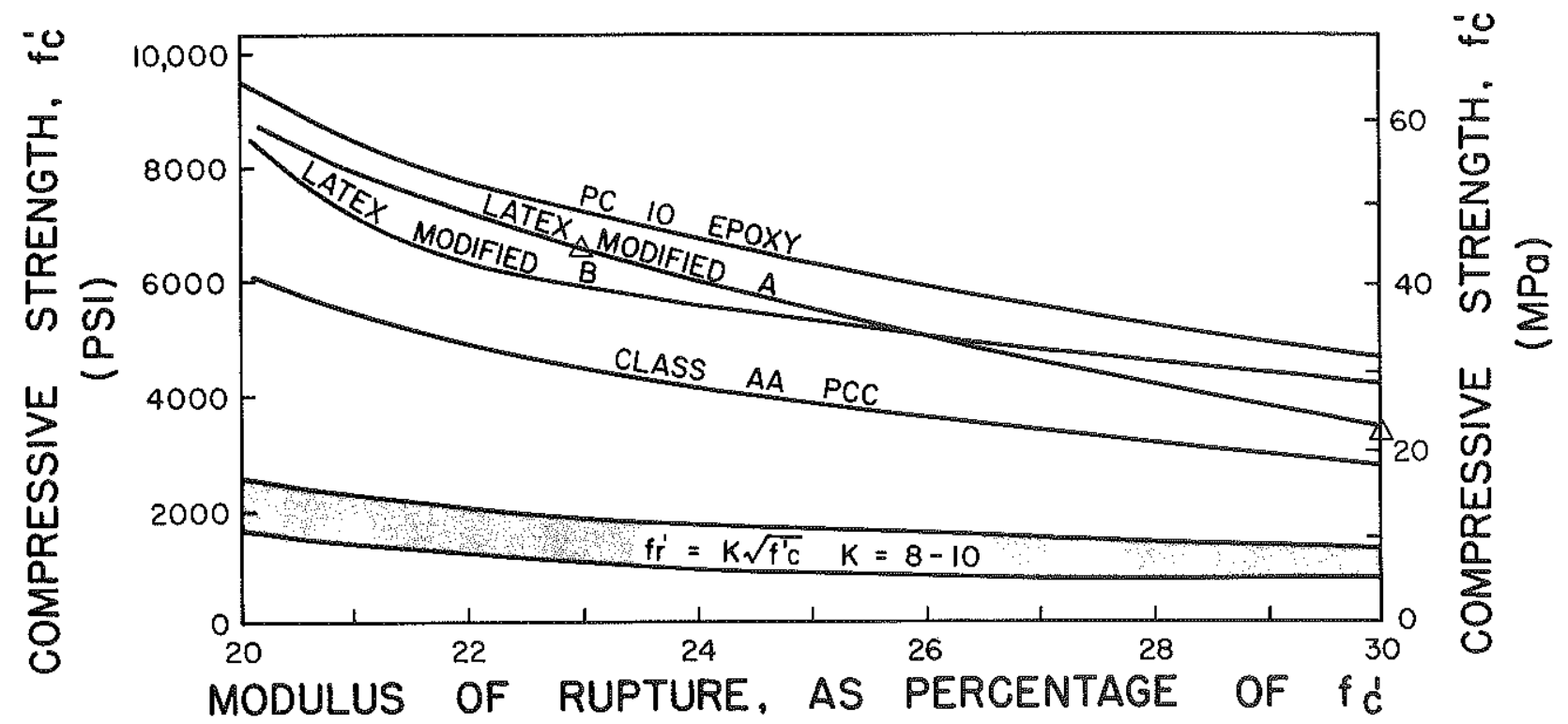

Figure 5a. Relationship between Campressive Strength and Modulus of Rupture; Latex and Epoxy Mixtures.

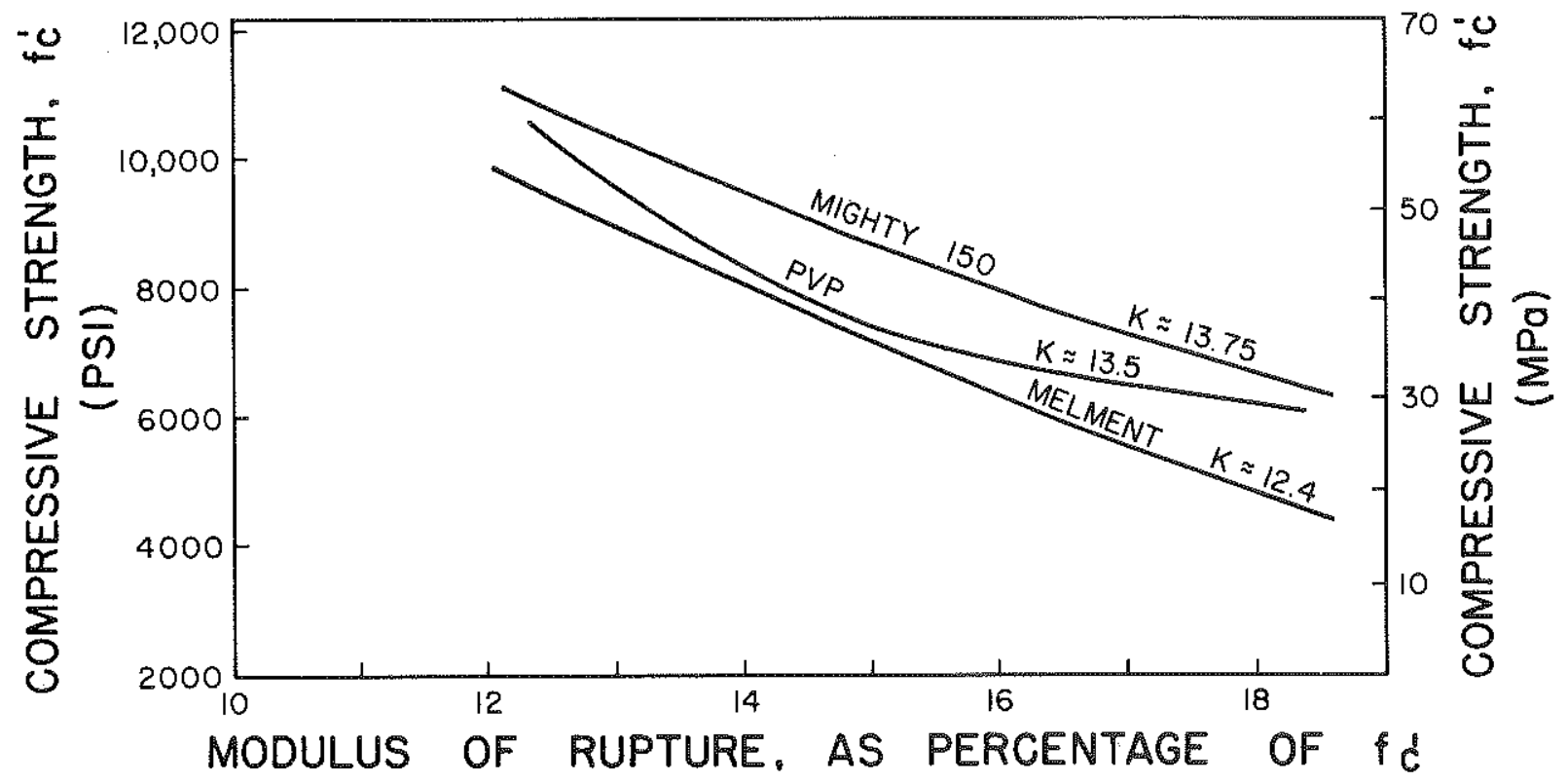

Figure 5b. Relationship between Compressive Strength and Modulus of Rupture; Superplasticized Concretes. 

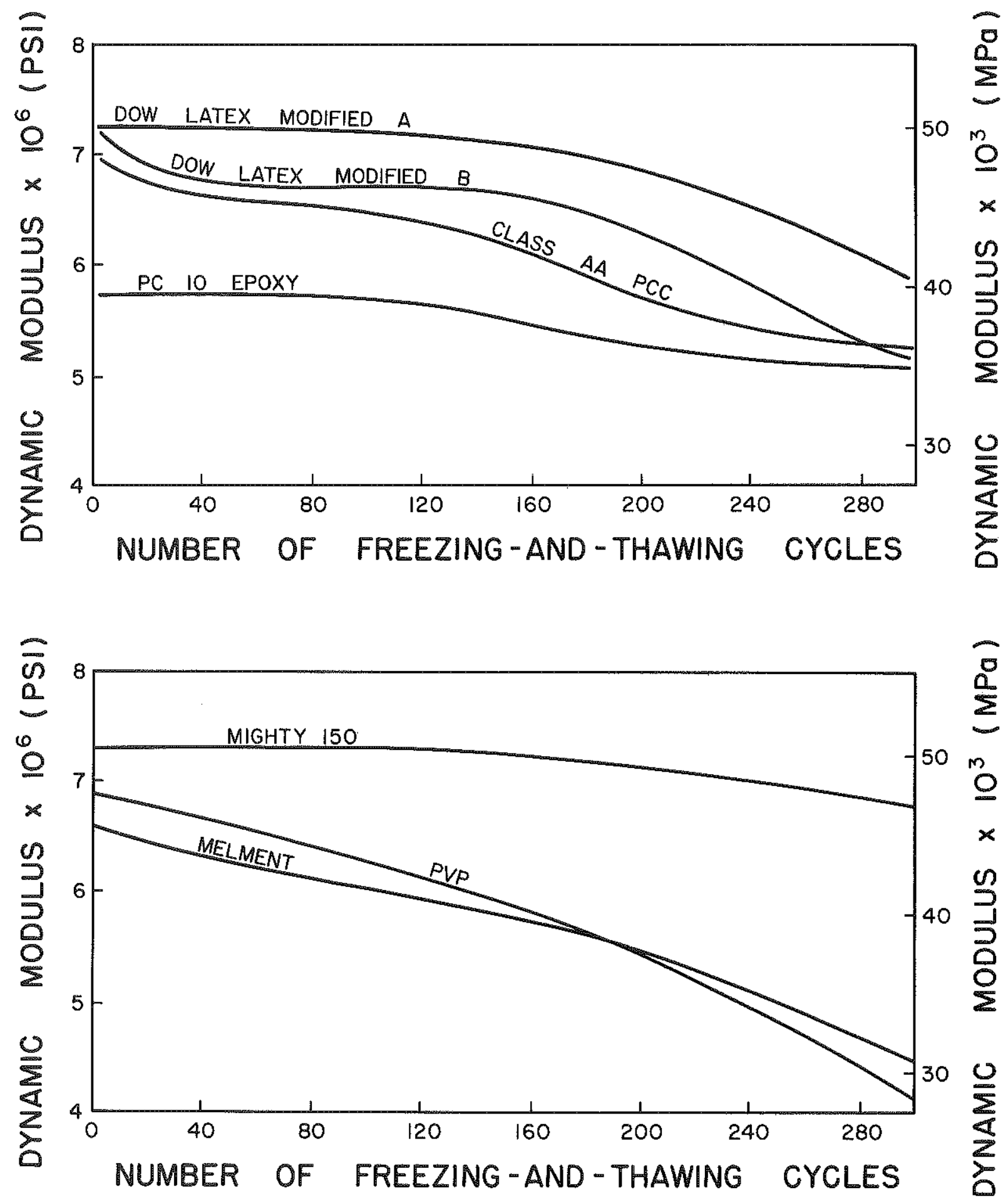

Figure 6. Average, Dynamic Moduli of Elasticity versus Time (Number of Cycles of Freezing and Thawing). 


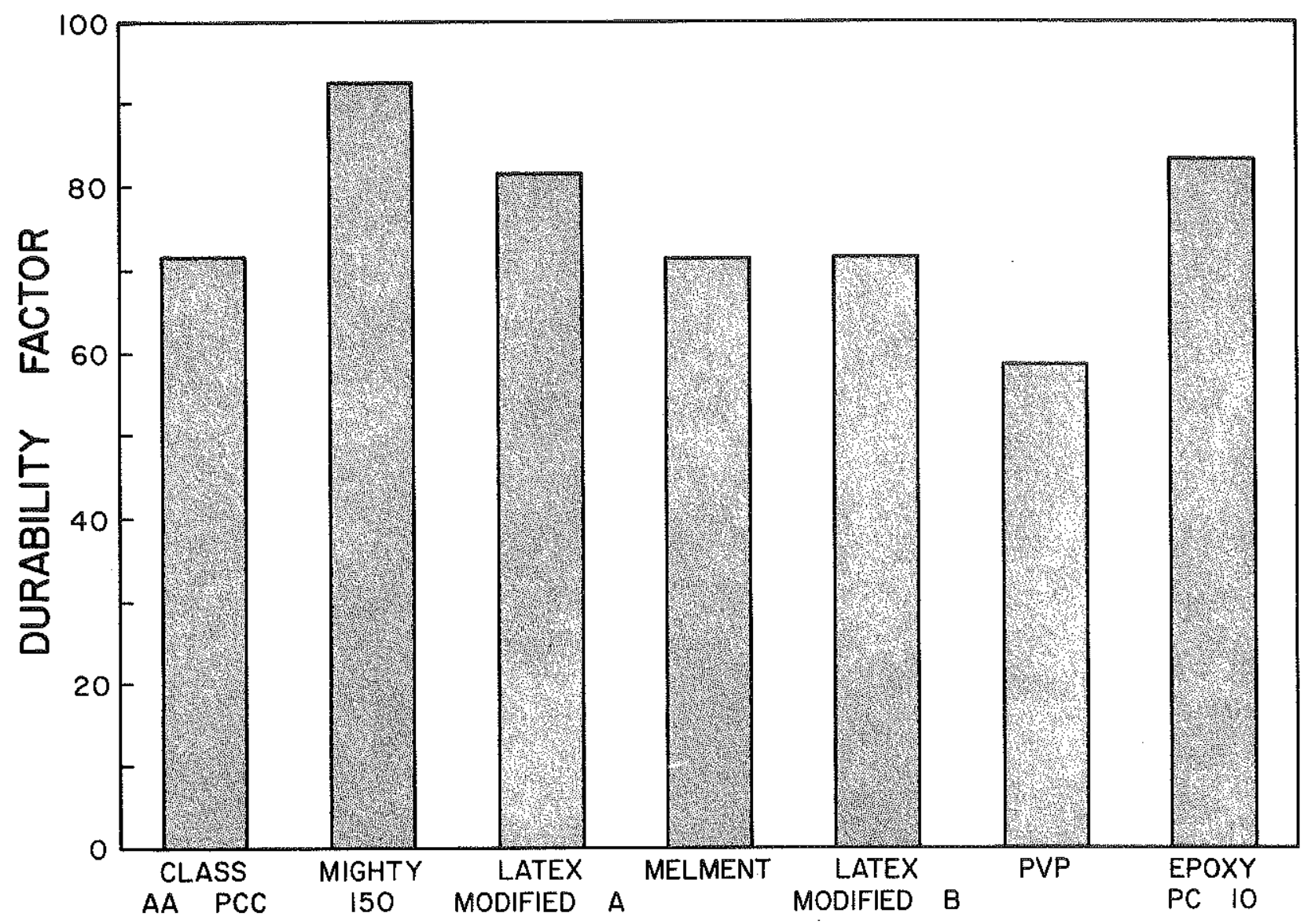

Figure 7. Comparison of Average Durability Factors. 


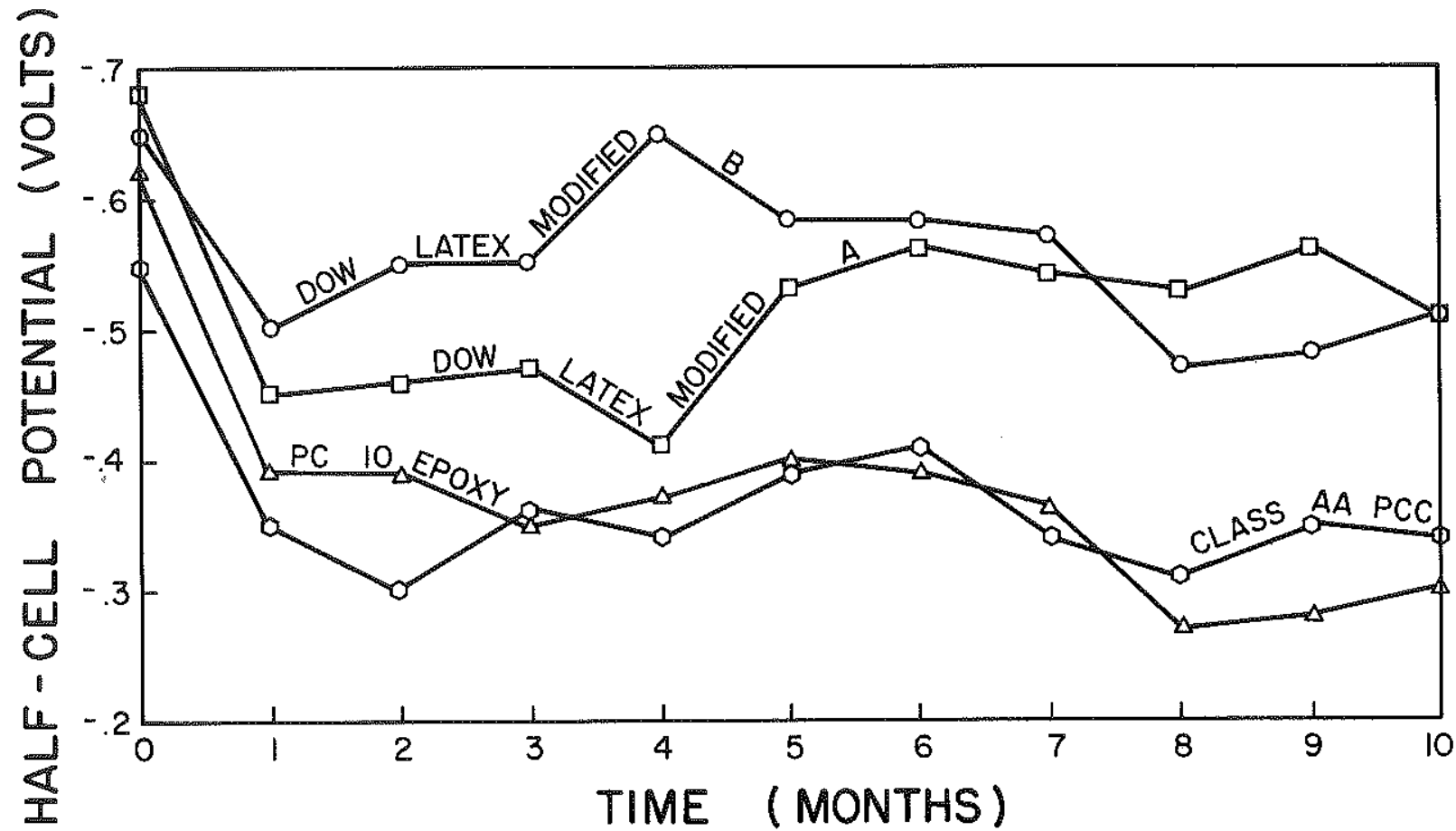

Figure 8. Half-Cell Potential versus Time; All Mixtures, Test Blocks; Referenced to Copper-Copper Sulfate Half-Cell.

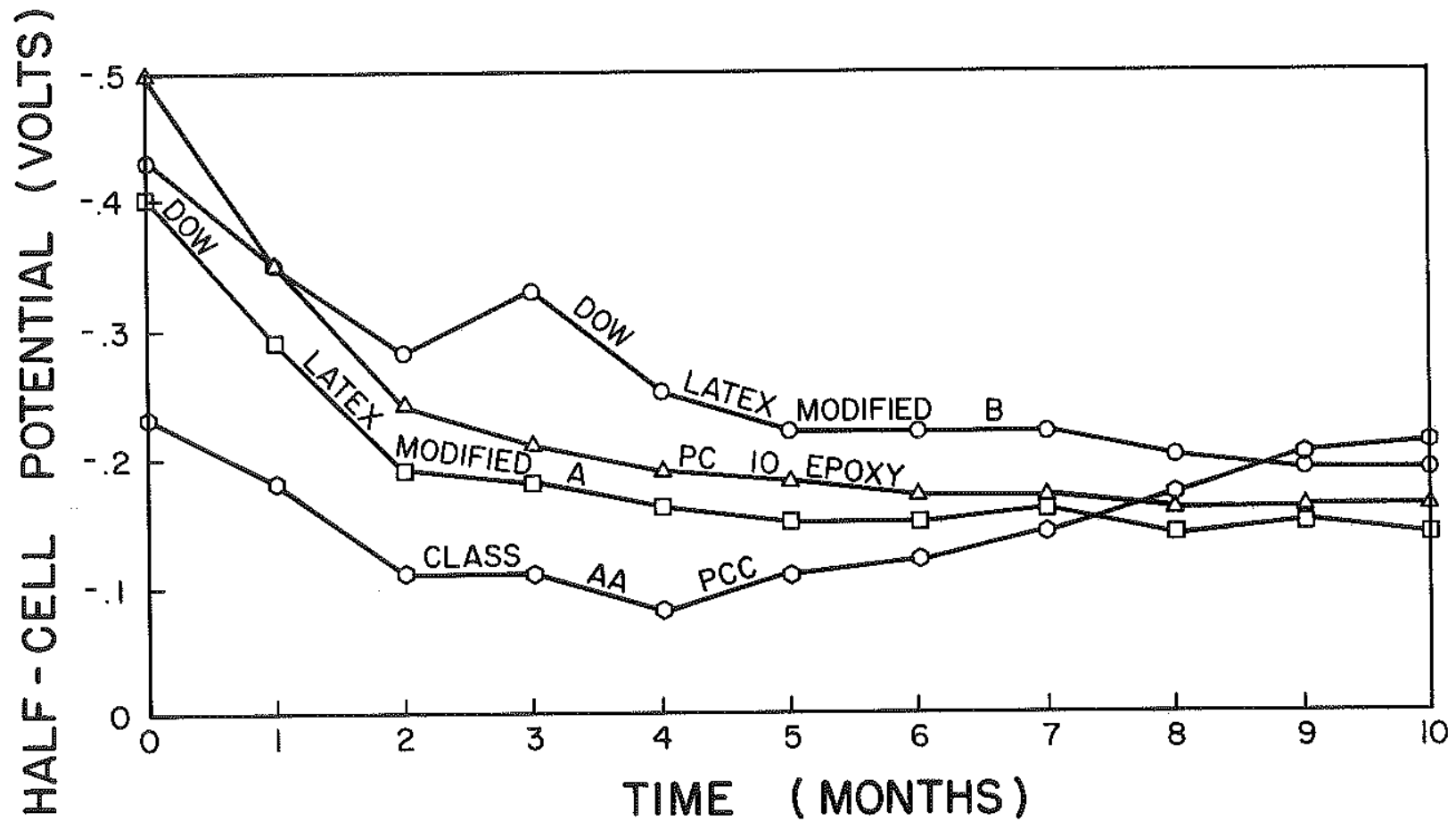

Figure 9. Half-Cell Potential versus Time; All Mixtures, Test Beams; Referenced to Calomel Half-Cell. 

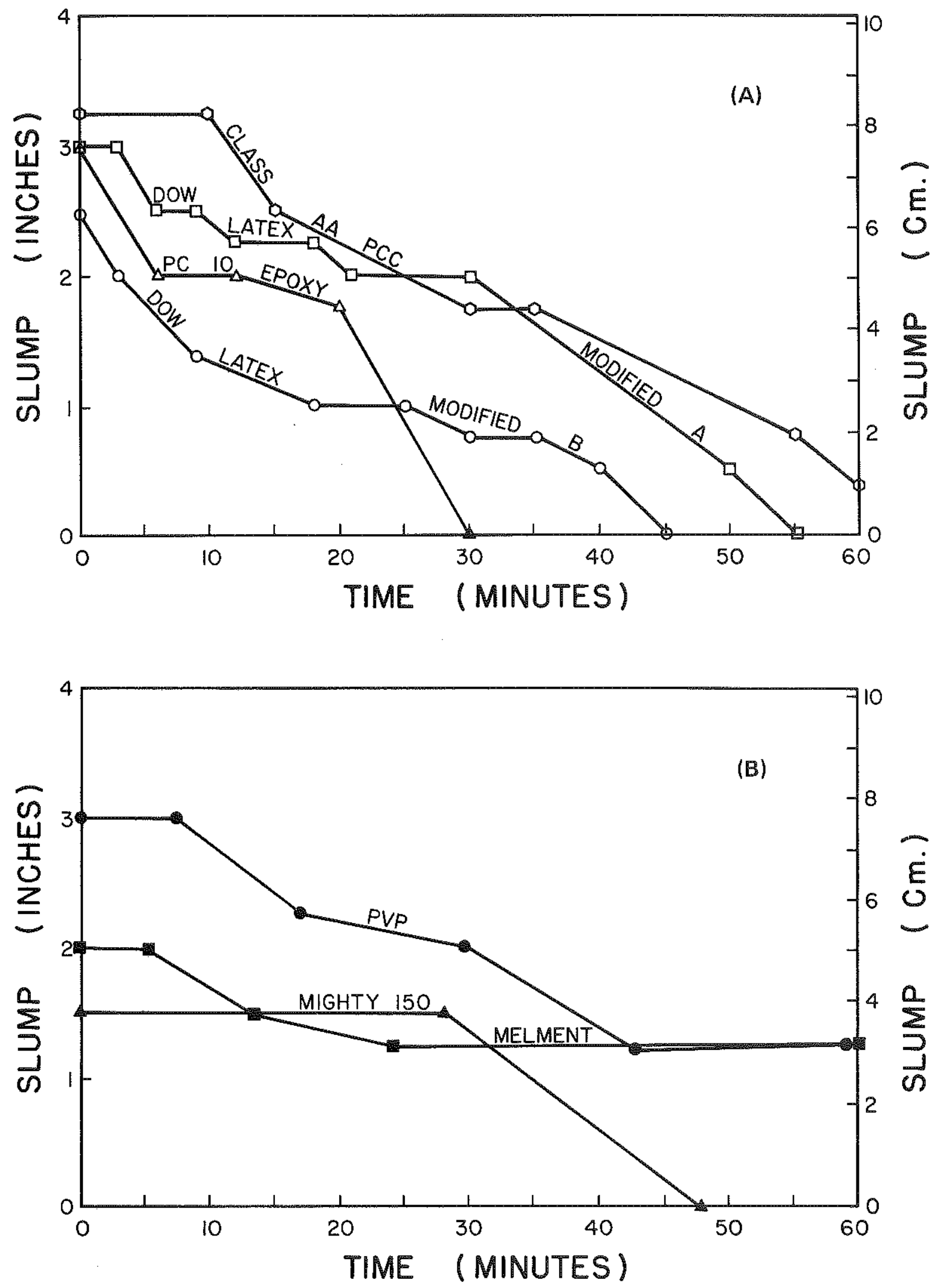

Figure 10. Slump-Loss Characteristics, All Concretes. 


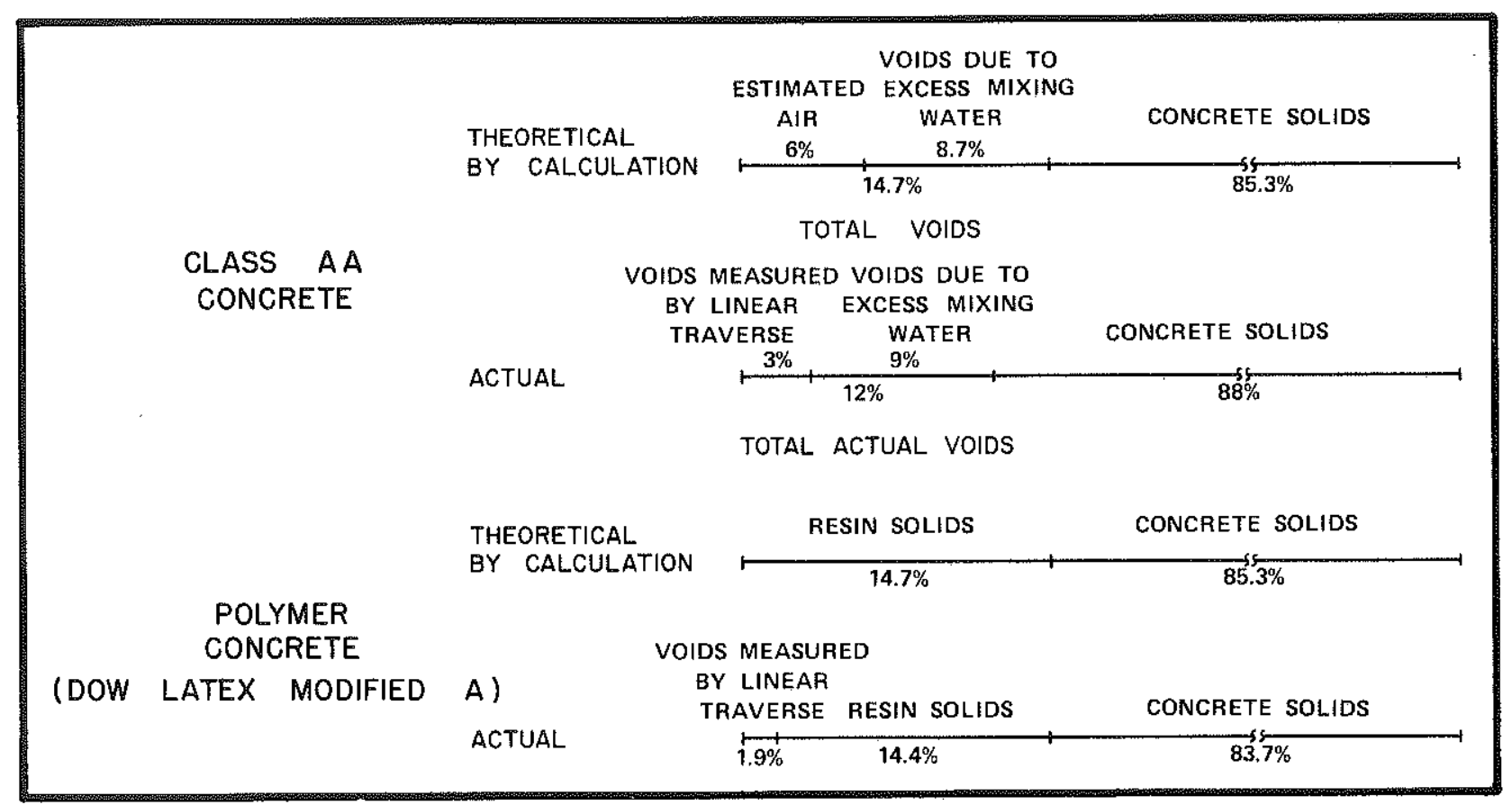

Figure 11. Voids-Solids Relationships; Class AA and Dow Latex Modifier A Concretes. 
TABLE 1. MIX DESIGNS

\begin{tabular}{|c|c|c|c|}
\hline & \multirow[t]{2}{*}{ ITEM } & \multicolumn{2}{|c|}{ MAGNITUDE } \\
\hline & & $\left(1 \mathrm{~b} / \mathrm{yd}^{3}\right)$ & $\left(\mathrm{kg} / \mathrm{m}^{3}\right)$ \\
\hline \multirow{4}{*}{ All Mixes } & Cement & 620 & 368 \\
\hline & Coarse Aggregate & 1814 & 1076 \\
\hline & Fine Aggregate & 1196 & 710 \\
\hline & Water Needed for Hydration & $152-186$ & $90-110$ \\
\hline \multirow{2}{*}{$\begin{array}{l}\text { Class AA } \\
\text { Concrete* }\end{array}$} & Water & 275 & 163 \\
\hline & & & \\
\hline \multirow{3}{*}{$\begin{array}{l}\text { Dow Latex } \\
\text { Modifier A }\end{array}$} & Percent Solids $=46-49 \approx 47$ & & \\
\hline & Amount of Liquid Required (includes $152 \mathrm{lb} / \mathrm{yd}^{3}$ & & \\
\hline & of water for hydration) $=152 / 0.53$ & 287 & 170 \\
\hline \multirow{3}{*}{$\begin{array}{l}\text { Dow Latex } \\
\text { Modifier B }\end{array}$} & Percent Solids $=48$ & & \\
\hline & Amount of Liquid Required (includes $152 \mathrm{Ib} / \mathrm{yd}^{3}$ & & \\
\hline & of water for hydration) $=152 / 0.52$ & 292 & 173 \\
\hline \multirow{4}{*}{$\begin{array}{l}\text { PC } 10 \\
\text { Epoxy }\end{array}$} & Amount of Epoxy Required & 129 & 76.5 \\
\hline & Part $\mathrm{A}=74.1 \%$ & 95.6 & 56.7 \\
\hline & Part $\mathrm{B}=25.9 \%$ & 33.4 & 19.8 \\
\hline & Water Needed for Hydration (minimum) & 152 & 90 \\
\hline \multirow{5}{*}{ Melment } & Percent Solids $=20$ & & \\
\hline & Amount of Liquid Added & & \\
\hline & $3 \%$ of weight of cement & 18.6 & 11.0 \\
\hline & Total Water in Mix & & \\
\hline & $w / c=0.3$ & 186 & 110 \\
\hline \multirow{5}{*}{ Mighty 150} & Percent Solids $=42$ & & \\
\hline & Amount of Liquid Added & & \\
\hline & $1.3 \%$ of weight of cement & 8.1 & 4.8 \\
\hline & Total Water in Mix & & \\
\hline & $w / c=0.3$ & 186 & 110 \\
\hline \multirow{5}{*}{ PVP } & Percent Solids $=40$ & & \\
\hline & Amount of Liquid Added & & \\
\hline & $5 \%$ of weight of cement & 31.0 & 18.4 \\
\hline & Total Water in Mix & & \\
\hline & $\mathrm{w} / \mathrm{c}=0.3$ & 186 & 110 \\
\hline
\end{tabular}

*1 $1 / 2$ to $21 / 2 \mathrm{in}$. (38 to $64 \mathrm{~mm}$ ) slump 6 percent air content 
TABLE 2. FRESH AND HARDENED CONCRETE TEST RESULTS FOR ALL MIXTURES

\begin{tabular}{|c|c|c|c|c|c|c|c|c|c|c|c|c|c|c|}
\hline \multirow{4}{*}{$\begin{array}{l}\text { CONCRETE } \\
\text { MIXTURE }\end{array}$} & \multirow{4}{*}{$\begin{array}{c}\text { AIR } \\
\text { CONTENT }\end{array}$} & \multirow{2}{*}{\multicolumn{4}{|c|}{ FRESH CONCRETE }} & \multicolumn{9}{|c|}{ HARDENED CONCRETE } \\
\hline & & & & & & \multirow{2}{*}{\multicolumn{3}{|c|}{ SPECIFIC GRAVITY }} & \multirow{2}{*}{\multicolumn{2}{|c|}{$\begin{array}{l}\text { UNIT WEIGHT } \\
\text { (BULK) }\end{array}$}} & \multirow{3}{*}{$\begin{array}{l}\text { PERMEABLE } \\
\text { VOIDS } \\
(\%)\end{array}$} & \multirow{3}{*}{$\begin{array}{l}\text { ABSORPTION } \\
\text { MOISTURE } \\
\text { (\%) }\end{array}$} & \multirow{3}{*}{$\begin{array}{c}\text { AIR } \\
\text { CONTENT } \\
(\%) \\
\text { LINEAR } \\
\text { TRAVERSE }\end{array}$} & \multirow{3}{*}{$\begin{array}{l}\text { PERMEABILITY } \\
\text { (cm/min) }\end{array}$} \\
\hline & & \multicolumn{2}{|c|}{ SLUMP } & \multicolumn{2}{|c|}{ UNIT WEIGHT } & & & & & & & & & \\
\hline & & (in.) & $(\mathrm{mm})$ & $\left(\mathrm{tb} / \mathrm{ft}^{3}\right)$ & $\left(\mathrm{kg} / \mathrm{m}^{3}\right)$ & DRY & BULK & APPARENT & $\left(\mathrm{b} b / \mathrm{ft}^{3}\right)$ & $\left(\mathrm{kg} / \mathrm{m}^{3}\right)$ & & & & \\
\hline $\begin{array}{l}\text { Dow Latex } \\
\text { Modifier A }\end{array}$ & 3.1 & 2.4 & 61 & 151.8 & 2,432 & 2.40 & 2.36 & 2.47 & 147.3 & 2,360 & 4.6 & 1.90 & 1.92 & 0.0 \\
\hline $\begin{array}{l}\text { Dow Le? } x \\
\text { Modifier } B\end{array}$ & 2.8 & 1.4 & 36 & 153.0 & 2,451 & 2.46 & 2.42 & 2.50 & 151.0 & 2,419 & 7.1 & 1.51 & 1.94 & 0.0 \\
\hline $\begin{array}{l}\text { PC } 10 \\
\text { Epoxy }\end{array}$ & 4.1 & 1.2 & 30 & I 49.5 & 2,395 & 2.41 & 2.33 & 2.52 & 145.4 & 2,329 & 7.6 & 3.29 & 2.73 & $1.19 \times 10^{-7}$ \\
\hline $\begin{array}{l}\text { Class } \\
\text { AA PCC }\end{array}$ & 4.2 & 2.4 & 61 & 148.5 & 2,379 & 2.44 & 2.30 & 2.68 & 143.5 & 2,299 & 14.0 & 6.10 & 3.06 & $2.91 \times 10^{-7}$ \\
\hline Melment & 2.0 & 3.0 & 76 & 152.8 & 2,448 & & & & & & & & & \\
\hline Mighty 150 & 2.4 & 4.5 & 114 & 154.6 & 2,476 & & & & & & & & & \\
\hline PVP & 2.9 & 2.4 & 60 & 155.4 & 2,489 & & & & & & & & & \\
\hline
\end{tabular}


TABLE 3. COMPRESSIVE AND FLEXURE STRENGTH TEST RESULTS

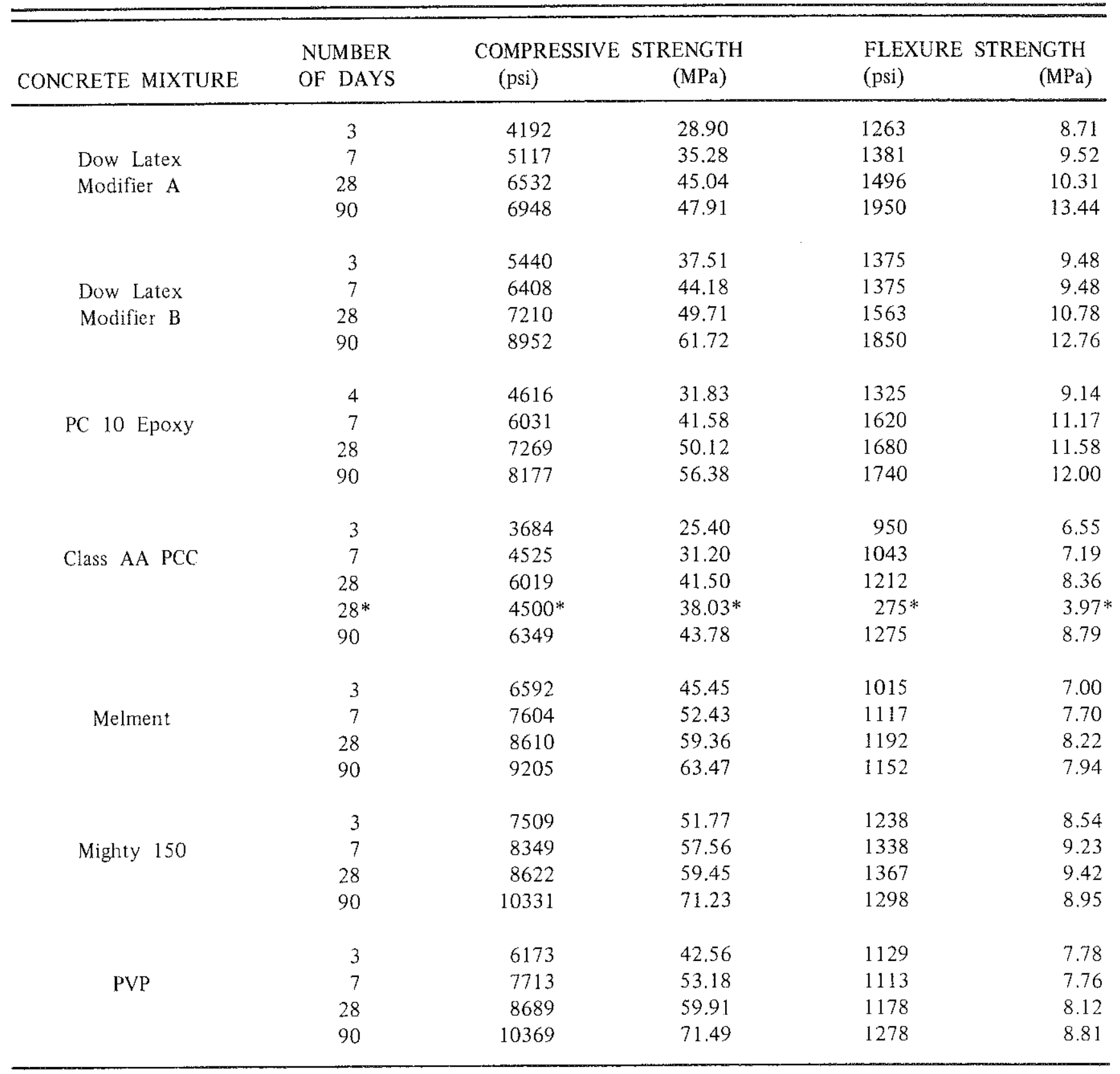

*Average, minimum requirements 
TABLE 4. AVERAGE DYNAMIC YOUNG'S MODULI OF ELASTICITY FOR ALL MIXTURES

\begin{tabular}{|c|c|c|c|c|c|c|c|c|c|c|c|}
\hline \multicolumn{3}{|c|}{$\begin{array}{l}\text { CLASS AA PCC } \\
\text { DF }^{*}=70.53\end{array}$} & \multicolumn{3}{|c|}{$\begin{array}{c}\text { LATEX MODIFIER A } \\
\text { DF }=80.76\end{array}$} & \multicolumn{3}{|c|}{$\begin{array}{c}\text { LATEX MODIFIER B } \\
\text { DF }=70.75\end{array}$} & \multicolumn{3}{|c|}{$\begin{array}{c}\text { PC } 10 \text { EPOXY } \\
\text { DF }=82.85\end{array}$} \\
\hline \multirow{2}{*}{$\begin{array}{l}\text { CYCLE } \\
\text { NUMBER }\end{array}$} & \multicolumn{2}{|c|}{$\mathrm{DE}^{* *}$} & \multirow{2}{*}{$\begin{array}{l}\text { CYCLE } \\
\text { NUMBER }\end{array}$} & \multicolumn{2}{|c|}{$\mathrm{DE}$} & \multirow{2}{*}{$\begin{array}{c}\text { CYCLE } \\
\text { NUMBER }\end{array}$} & \multicolumn{2}{|c|}{$\mathrm{DE}$} & \multirow{2}{*}{$\begin{array}{l}\text { CYCLE } \\
\text { NUMBER }\end{array}$} & \multicolumn{2}{|c|}{$\mathrm{DE}$} \\
\hline & $\begin{array}{c}\text { psi } \\
\left(\times 10^{-6}\right)\end{array}$ & $\begin{array}{c}\mathrm{MPa} \\
\left(\times 10^{-4}\right)\end{array}$ & & $\begin{array}{c}p s i \\
\left(\times 10^{-6}\right)\end{array}$ & $\begin{array}{c}\mathrm{MPa} \\
\left(\times 10^{-4}\right)\end{array}$ & & $\begin{array}{c}\mathrm{psi} \\
\left(\times 10^{-6}\right)\end{array}$ & $\begin{array}{c}\mathrm{MPa} \\
\left(\times 10^{-4}\right)\end{array}$ & & $\begin{array}{c}\mathrm{psi} \\
\left(\mathrm{x} 10^{-6}\right)\end{array}$ & $\begin{array}{c}\mathrm{MPa} \\
\left(\mathrm{x} 10^{-4}\right)\end{array}$ \\
\hline 0 & 6.95 & 4.79 & 0 & 7.07 & 4.87 & 0 & 7.29 & 5.03 & 0 & 5.72 & 3.94 \\
\hline 24 & 6.65 & 4.58 & 16 & 7.26 & 5.01 & 25 & 6.79 & 4.68 & 73 & 5.70 & 3.93 \\
\hline 46 & 6.60 & 4.55 & 63 & 7.27 & 5.01 & 57 & 6.74 & 4.65 & 129 & 5.61 & 3.87 \\
\hline 78 & 6.41 & 4.42 & 114 & 7.08 & 4.88 & 81 & 6.69 & 4.61 & 189 & 5.36 & 3.70 \\
\hline 102 & 6.39 & $4.4 \mathrm{I}$ & 138 & 7.22 & 4.98 & 101 & 6.69 & 4.61 & 266 & 5.13 & 3.54 \\
\hline 134 & 6.34 & 4.37 & 160 & 7.12 & 4.91 & 130 & 6.61 & 4.56 & 299 & 4.76 & 3.28 \\
\hline 158 & 6.09 & 4.20 & 192 & 6.82 & 4.70 & ISI & 6.52 & 4.50 & & & \\
\hline 191 & 5.89 & 4.06 & 216 & 6.74 & 4.65 & 182 & 6.52 & 4.50 & & & \\
\hline 225 & 5.38 & 3.71 & 248 & 6.55 & 4.52 & 233 & 5.80 & 4.00 & ${ }^{*} \mathrm{DF}=\mathrm{D}$ & ility Factor & \\
\hline 249 & 5.38 & 3.71 & 272 & 6.22 & 4.29 & 264 & 5.47 & 3.77 & ${ }^{* *} \mathrm{DE}=\mathrm{D}$ & mic Young & Modulus \\
\hline 269 & 5.38 & 3.71 & 306 & 5.60 & 3.86 & 293 & 5.19 & 3.58 & & lasticity & \\
\hline 299 & 4.92 & 3.40 & & & & 300 & 5.12 & 3.53 & & & \\
\hline & $\begin{array}{l}\text { GHTY } 15 \\
F=91.3\end{array}$ & & & $\begin{array}{l}\text { MELMENT } \\
\mathrm{F}=70.0\end{array}$ & & & $\begin{array}{c}\text { PVP } \\
F=59.7\end{array}$ & & & & \\
\hline \multirow[b]{2}{*}{$\begin{array}{l}\text { CYCLE } \\
\text { NUMBER }\end{array}$} & \multicolumn{2}{|c|}{$\mathrm{DE}$} & \multirow[b]{2}{*}{$\begin{array}{l}\text { CYCLE } \\
\text { NUMBER }\end{array}$} & \multicolumn{2}{|c|}{$\mathrm{DE}$} & \multirow[b]{2}{*}{$\begin{array}{l}\text { CYCLE } \\
\text { NUMBER }\end{array}$} & \multicolumn{2}{|c|}{$\mathrm{DE}$} & & & \\
\hline & $\begin{array}{c}p s ̦ i \\
\left(\times 10^{-6}\right)\end{array}$ & $\begin{array}{c}\mathrm{MPa} \\
\left(\times 10^{-4}\right)\end{array}$ & & $\begin{array}{c}\text { psi } \\
\left(\times 10^{-6}\right)\end{array}$ & $\begin{array}{c}\mathrm{MPa} \\
\left(x 10^{-4}\right)\end{array}$ & & $\left(x \perp 0^{-6}\right)$ & $\begin{array}{c}\mathrm{MPa} \\
\left(\times 10^{-4}\right)\end{array}$ & & & \\
\hline 0 & 7.33 & 5.05 & 0 & 6.62 & 4.56 & 0 & 6.93 & 4.78 & & & \\
\hline 6 & 7.21 & 4.97 & 41 & 6.31 & 4.35 & 38 & 6.67 & 4.60 & & & \\
\hline 117 & 7.23 & 4.99 & 81 & 6.17 & 4.25 & 94 & 6.43 & 4.43 & & & \\
\hline 150 & 7.23 & 4.99 & 132 & 5.89 & 4.06 & 182 & 5.71 & 3.94 & & & \\
\hline 176 & 7.12 & 4.91 & 196 & 5.47 & 3.77 & 239 & 4.73 & 3.26 & & & \\
\hline 223 & 7.08 & 4.88 & 255 & 4.92 & 3.40 & 279 & 4.24 & 2.92 & & & \\
\hline 247 & 7.37 & 5.08 & 273 & 4.73 & 3.26 & 289 & 4.15 & 2.86 & & & \\
\hline 289 & 6.84 & 4.71 & 300 & 4.64 & 3.20 & & & & & & \\
\hline 300 & 6.69 & 4.61 & & & & & & & & & \\
\hline
\end{tabular}

